\title{
Shattering the Myth of Separate Worlds: Negotiating Non-Work Identities at Work
}

\section{Citation}

Ramarajan, Lakshmi, and Erin M. Reid. "Shattering the Myth of Separate Worlds: Negotiating Non-Work Identities at Work." Academy of Management Review 38, no. 4 (October 2013): 621644.

\section{Published Version}

https://doi.org/10.5465/amr.2011.0314

\section{Permanent link}

http://nrs.harvard.edu/urn-3:HUL.InstRepos:41266382

\section{Terms of Use}

This article was downloaded from Harvard University's DASH repository, and is made available under the terms and conditions applicable to Other Posted Material, as set forth at http:// nrs.harvard.edu/urn-3:HUL.InstRepos:dash.current.terms-of-use\#LAA

\section{Share Your Story}

The Harvard community has made this article openly available.

Please share how this access benefits you. Submit a story.

\section{Accessibility}




\title{
SHATTERING THE MYTH OF SEPARATE WORLDS: NEGOTIATING NONWORK IDENTITIES AT WORK
}

\author{
LAKSHMI RAMARAJAN \\ Harvard Business School \\ ERIN REID \\ Boston University
}

\begin{abstract}
How much of our self is defined by our work? Fundamental changes in the social organization of work are destabilizing the relationship between work and the self. As $\alpha$ result, parts of the self traditionally considered outside the domain of work-that is, nonwork identities-are increasingly affected by organizations and occupations. Based on an interdisciplinary review of literature on identity and work, we develop a model of how people negotiate nonwork identities (e.g., national, gender, family) in the context of organizational/occupational pressures and personal preferences regarding this identity. We propose that the dual forces of pressures and preferences vary from inclusion (e.g., incorporating the nonwork identity within the work identity) to exclusion (e.g., keeping the identities separate). We suggest that the alignment or misalignment of these pressures and preferences shapes people's experience of the power relationship between themselves and their organization/occupation and affects how they manage their nonwork identities. We describe how people enact different nonwork identity management strategies-namely, assenting to, complying with, resisting, or inverting the pressures-and delineate the consequences of these strategies for people and their organizations/occupations.
\end{abstract}

How much of our self is defined by our work? This fairly simple question is surprisingly difficult to answer. Selves, people's self-definitions and meanings constructed through interaction with others (Goffman, 1959; James, 1890; Mead, 1934), encompass multiple identities developed within different aspects of social life (Burke \& Stets, 2009; James, 1890). For several decades an uneasy "myth of separate worlds" (Kanter, 1977) has served to roughly define identities considered relevant to and affected by work (e.g., managerial, occupational) and those considered nei-

Both authors contributed equally to this manuscript. We thank our editor, Karen Ashcraft, and our three anonymous reviewers for their helpful feedback. We also thank Michel Anteby, Sigal Barsade, Julie Battilana, Robin Ely, Herminia Ibarra, Deborah Kolb, Joshua Margolis, Kathleen McGinn, Celia Moore, Tsedal Neeley, Otilia Obodaru, Jennifer Petriglieri, Michael Pratt, Linda Putnam, Nancy Rothbard, and Spela Trefalt for their advice; Nichole Gregg and Alexis Lefort for their assistance; and Nick Levitt and Alex Muggah for their support. We appreciate the feedback we received from audiences at the 2011 and 2012 Academy of Management annual meetings, the 2012 Wharton People and Organizations conference, and members of the GRO seminar group. ther relevant to nor affected by work (e.g., religious, national, gender, family). However, declining job stability (Cappelli, 1999; Kalleberg, 2009), rising workforce diversity (Calas \& Smircich, 1996; Davis-Blake \& Broschak, 2009; Deal, Altman, \& Rogelberg, 2010), and the spread of communication technologies (Barley, Meyerson, \& Grodal, 2011; Scott, 1999; Scott \& Timmerman, 1999) are now blurring the distinctions between work and nonwork life domains such that many workers, their organizations, and their occupations must now renegotiate the relationship between work and nonwork identities. How these dynamics unfold and the implications for workers' selves, at work and outside work, remain unclear.

Management research on identity has primarily explored how organizations and occupations influence and control people's work-related identities (Alvesson \& Willmott, 2002; Ashforth \& Kreiner, 1999; Bartel, 2001; Dutton, Dukerich, \& Harquail, 1994; Kunda, 1992) but has focused less on whether or how this control may extend to nonwork identities. In contrast, organizational research in the domains of communication 
(Borker, 1993; Buzzonell \& Liu, 2005; Jorgenson, 2002), gender and diversity (Blair-Loy, 2003; Ely \& Thomas, 2000; Konrad, 2003), work and family (Ashforth, Kreiner, \& Fugate, 2000; Kreiner, Hollensbe, \& Sheep, 2009; Pratt \& Rosa, 2003; Rothbard, Phillips, \& Dumas, 2005), and occupational community (Adler \& Adler, 1999; Davis, 1986; Kidder, 2006) has challenged the notion that work identity is separable from other parts of the self. For example, gender identity is known to be intertwined with organizational and occupational identity (Ely, 1995), yet this insight is not well incorporated into most management scholarship (Ashcraft, 2012). One potential reason for this oversight is that this research on nonwork identities is rooted in several distinct scholarly conversations, limiting our ability to develop a more general understanding of how organizations/occupations affect how people manage these other parts of their selves in relation to their work identities.

Explaining how people manage this relationship is further hindered by the fact that research on organizational and occupational control over workers' identities (Alvesson \& Willmott, 2002; Karreman \& Alvesson, 2004; Pratt, 2000) has generally proceeded separately from research on identity construction, or people's desires to create, maintain, and revise particular identities (Anteby, 2008; Buzzanell et al., 2005; Dutton, Roberts, \& Bednar, 2010; Ibarra, 1999; Svenningson \& Alvesson, 2003). As a result, we understand little about how people interpret and respond to different sorts of organizational/ occupational pressures on their identities. Indeed, identity scholors have called for "much more research ... on the combined dynamics of identity desire and imposition, as well as on their associated power implications" (Anteby, 2013: 1285), and attention to "extra-individual forces" in identity processes (Alvesson, Ashcraft, \& Thomas, 2008: 18).

In this article we develop new theory about how people negotiate identities traditionally considered nonwork at work. We begin by discussing how changes in the social organization of work are eroding the boundaries between work and nonwork identities. Based on an interdisciplinary literature review of empirical research on work and identity, we induce a model of how people navigate organizational/ occupational pressures on a nonwork identity in light of their personal preferences regarding the identity. We theorize that the dual forces of pressures and preferences vary along an axis that ranges from total inclusion of the nonwork identity within the work identity to total exclusion from the work identity. Based on the alignment of these dual forces, people have divergent experiences of the power relationship between themselves and the organization/occupation. The greater the alignment, the more likely people are to remain unaware of this power relationship or to experience it as enabling. The greater the misalignment, the more likely people are to acutely experience the power relationship as a constraint. These experiences affect the nonwork identity management strategies that people craft.

We identify four strategies: assenting to, complying with, resisting, or inverting the pressures. We locate several commonly studied identity states (e.g., concealed, revealed, integrated) as outcomes of these strategies and call attention to how the same states may emerge from distinct strategies. We delineate the consequences of this process for people, organizations, and occupations and close by discussing contributions to scholarship on work and identity.

\section{CHANGES IN THE SOCIAL ORGANIZATION OF WORK}

The work/nonwork boundary has varied over time, geographies, and social divisions (Ashforth, 2001; Lamont \& Molnór, 2002; NippertEng, 1996). People have long congregated in occupational communities (Van Maanen \& Barley, 1984), social groups wherein work is deeply intermingled with all aspects of life-for example, auto, industrial, and chemical plant workers (Goldthorpe, Lockwood, Bechhofer, \& Platt, 1968); miners (Lucas, 2009); steelworkers (MacKenzie et al., 2006); and lacemakers (Sharpe, 2010). For many, however, the post-World War II era generally has been characterized by the myth of separate worlds: an assumption that work and nonwork are starkly divided parts of life (Kanter, 1977; Zelizer, 2005). While this myth has never matched most people's experiences, it informs the design of work in most organizations and occupations (Bailyn, 2006; Williams, 2000). However, three changes in the social organization of work are now overtly eroding this myth and reshaping the boundaries between work and nonwork identities: declining job security, increas- 
ing workforce diversity, and the spread of communication technology.

\section{Declining Job Security}

Declines in job security and the now precarious nature of work for people across the economic spectrum have been amply documented (Cappelli, 1999; DiTomaso, 2001; Kalleberg, 2009; Smith, 2002). The nature of lifetime employment has consequently shifted from employment by a single organization (Whyte, 1957) to serial employment across many organizations (Arthur \& Rousseau, 1996; Briscoe, Hall, \& Demuth, 2006), punctuated by spells of unemployment (Kalleberg, 2009). Scholars have taken two perspectives on the implications of job insecurity and high mobility for work identity; we build on each, extending the analysis to nonwork identities.

First, some argue that these changes have shifted the locus of work identification from organizations to occupations and careers (Albert, Ashforth, \& Dutton, 2000; Bartel, Blader, \& Wrzesniewski, 2007; Thatcher \& Zhu, 2006). Since occupational communities typically integrate work with nonwork parts of life (Van Maanen \& Barley, 1984), a shift in the locus of work identity toward occupations is likely to exacerbate the blurring of boundaries between work and nonwork identities. Because social networks are key to successful job searches (Granovetter, 1973), people may also have to draw more frequently on nonwork relationships as they seek new employment (Higgins, 2001; Higgins \& Thomas, 2001; Ibarra, 2003; Strangleman, 2001), thereby making nonwork identities more relevant to work identity.

A second view posits that "flexible capitalism's" constant assaults of layoffs, contract work, and temporary jobs have eroded work identity altogether (Sennett, 1998; Strangleman, 2007). In this case nonwork identities may also become more salient in work contexts as people rely on their nonwork identities as sources of meaning and tie these nonwork identities to their work (Lane, 2009). Erosion of a work identity can also threaten the nonwork identities with which it is associated (e.g., unemployed men may experience a threat to their masculine identity; Buzzonell \& Turner, 2003). Thus, whether job insecurity shifts the locus of work identity or erodes it entirely, it alters the relationship between work and nonwork identities.

\section{Increasing Demographic Diversity}

Over the last several decades, the entry of women and numerous ethnic and racial groups into many organizations (Bell \& Nkomo, 2003; Calas \& Smircich, 1996), generational changes (Callonan \& Greenhaus, 2008; Deal et al., 2010), and the global outsourcing of labor (Corbett, 2004; Davis-Blake \& Broschak, 2009) have altered the demography of organizational and occupational workforces. These changes erode the boundaries between work and nonwork identities for many people (Phillips, Rothbard, \& Dumas, 2009; Roberts, 2005).

Although women and minorities are making their way into previously homogeneous roles and occupations, organizational and occupational entry, socialization, and promotion processes are often based on the images of previous successful workers (Cheryan, Plaut, Davies, \& Steele, 2009; Gorman, 2005). Not fitting this image might heighten workers' attention to their disqualifying nonwork identities, as experienced by a black woman working on Wall Street, who stated:

[I] never felt like more of $\alpha$ black woman with all of the negative stereotypes attached than I did when I was working at Morgan Stanley.... I felt like the first thing people saw when they looked at me was not a bright person who had been admitted to the analyst class but a black woman (Ho, 2009: 61).

Because these images of an ideal worker are resistant to change (Costello, 2005; Ridgeway, 2011), demographic changes are unlikely to immediately disrupt the image; rather, they are more likely to increase the proportion of workers who, like this woman, feel they do not fit the image and are consequently more aware of particular nonwork identities. Greater diversity may also heighten the salience of nonwork identities for members of traditional majority groups (Brief et al., 2005; Chattopadhyay, 1999; Taylor, 1998; Tsui, Egan, \& O'Reilly, 1992); a study of workgroup gender composition found that men experience their gender identity as most salient both when women are numerically rare and when they are numerically dominant (Randel, 2002).

Heightened diversity may also make nonwork identities more salient for all workers simply by placing people more frequently in interactions with demographically different colleagues. In 
such circumstances the need to have others recognize and comprehend one's important identities (Swann, Polzer, Seyle, \& Ko, 2004; Thatcher \& Greer, 2008) and the need to learn about others' nonwork identities to work effectively across group differences (Brickson, 2000; Ely \& Thomas, 2000) are likely to make nonwork identities more salient to people than in the more homogenous organizations/occupations of the past, but also more challenging to manage (Phillips et al., 2009).

\section{Proliferating Communication Technology}

Communication technologies have also altered the relationship between people's work and nonwork identities (Castells, 1998, 1999). Such technologies have encouraged telecommuting (Bailey \& Kurland, 2002) and have changed where and when work is done (Barley et al., 2011; Leonardi \& Bailey, 2008) such that workers can now expect to be "on call" in times and places formerly protected from work (Perlow, 2012; Presser, 1998). These new work practices disrupt the practices and social interactions that provide a basis for work identities (Scott, 1997; Scott \& Timmerman, 1999; Thatcher \& Zhu, 2006; Wiesenfeld, Raghuram, \& Garud, 1999). By bringing social interactions and experiences routinely associated with work into times and spaces normally associated with nonwork, these technologies may also blur the boundaries between people's work and nonwork identities, an effect evident in the following quote:

With my cell phone, two-way pager, and Palm Pilot, I can work anywhere. I've worked escalations in Disney World. In fact, I can remember exactly where I was because it made such an impression on me. I think it was the Popeye thing. It was actually in Universal Studios. So the kids are going down the whatever and I'm on the phone with an engineer talking to him about a problem with a storage array (Barley et al., 2011: 896).

While this manager was reported as happy that his various devices enabled him to fuse his work with his family life, others may experience them as interfering with family life (Chesley, 2005) and feel they have little control over when and how they use such devices (Barley et al., 2011).

Such technologies may also enable traditionally visible nonwork identities to be kept "invisible" (Clair, Beatty, \& Maclean, 2005). For exam- ple, people may use technology-mediated communication to conceal visible but stigmatized social categories, such as race or ethnicity, as in the case of Indian call center agents posing as Americans over the phone (Poster, 2007). Thus, such technologies may also reshape the boundaries between work and nonwork identities by destabilizing their enactment in time and space. Together, these three changes in the social organization are reshaping the boundaries between work and nonwork identities, yet organizational scholarship on identity has not kept pace.

\section{Extant Scholarship on Work, Identity, and Nonwork Identities}

Although management scholars have developed an understanding of organizational/ occupational control over work identities and people's desires to construct particular work identities, they have largely not extended this analysis to nonwork identities. For example, scholars have explored the ways in which organizations and occupations control the development of particular work identities, a process referred to as identity management or identity regulation (Alvesson \& Willmott, 2002; Pratt, 2000). Examples include career transitions, which represent structural pressures for people to reconstruct their work identities to match their new roles (Ibarra \& Barbulescu, 2010), work tasks that can influence the content of occupational identities (Becker \& Carper, 1956; Pratt, Rockmann, \& Kaufmann, 2006), and organizational ceremonies that encourage people to develop particular work identities (Karreman \& Alvesson, 2004; Kunda, 1992).

The little management research that has examined how organizations and occupations might influence workers' nonwork identities has focused on a particular nonwork identity. For example, Kreiner, Hollensbe, and Sheep (2006) considered how priests negotiate an "optimal balance" between their personal and occupational identities; Creed, DeJordy, and Lok (2010) examined how gay priests enact their sexual identities in a professional context; and Ely and Meyerson (2010) showed how on organizational initiative designed to enhance safety and effectiveness on offshore oil platforms created a culture that unintentionally reshaped male workers' conceptions of themselves as men. Each of 
these studies articulates clearly that work influences how people enact personal, sexual, or gender identities at work. However, the findings of these and other similar studies have not been aggregated to offer a cohesive understanding of how work may influence people's enactment of a wide range of nonwork identities. The processes they trace are thus limited in their generalizability.

Research on organizational communication (Barker, 1993; Jorgenson, 2002), gender and diversity (Blair-Loy, 2003; Ely \& Thomas, 2000; Ladge, Clair, \& Greenberg, 2012; Stickney \& Konrad, 2007), work and family (Ashforth et al., 2000; Greenhaus \& Beutell, 1985; Greenhaus \& Powell, 2006; Kreiner et al., 2009; Pratt \& Rosa, 2003; Rothbard, 2001), and occupational community (Adler \& Adler, 1999; Davis, 1986; Kidder, 2006) has more extensively examined the relationship between people's work and nonwork lives, often using an identity lens. For example, research on organizational communication suggests that working mothers struggle to construct identities that combine work and gender roles (Buzzanell et al., 2005), research on diversity suggests that minorities struggle with questions of exclusion of aspects of self that are stigmatized from workplaces (Clair et al., 2005; Phillips et al., 2009; Poster, 2007), and research on work and family roles suggests that individuals manage their multiple role identities along a continuum from integration to segmentation (Ashforth et al., 2000; Nippert-Eng, 1996; Rothbord et al., 2005). Although research in each of these domains recognizes that people negotiate specific nonwork identities at work, these insights have yet to be integrated to shed new light on how organizational/occupational forces may influence nonwork identities more broadly.

\section{The Role of Power in Identity Control and Construction}

Furthermore, although scholars have examined organizational/occupational control over identities and people's construction of work identities separately, they have largely not examined the multilevel and interactive nature of this process (Anteby, in press). Yet theories of power suggest that identity control and identity construction are necessarily intertwined. Power, the copacity to influence others to achieve particular ends (Emerson, 1962; French \& Raven,
1959), is an inherently relational phenomenon (Anderson \& Galinsky, 2006; Emerson, 1962). Power operates both "externally in practices, forms of knowledge, and modes of rationality that are routinely deployed in an effort to shape people's conduct, wishes, and needs (Knights \& Vurdubakis, 1994) and internally in the felt need to accommodate or resist such efforts (Alvesson \& Billing, 1997; Covaleski, Dirsmith, Heian, \& Samuel, 1998)" (Ely \& Padavic, 2007: 1131). Thus, the interplay of organizational/occupational attempts to control identities with people's desires to construct particular identities may lead people to experience the power relationship between themselves and the organization/occupation in different ways.

\section{TOWARD A CONCEPTUAL MODEL: DEFINING INITIAL CONDITIONS}

\section{An Interdisciplinary Review of Empirical Research on Work and Identity}

To develop our model, we first conducted a literature search for empirical articles in a broad range of organizational journals dating from 1990 through 2012 that contained terms related to social changes (i.e., job insecurity, diversity, and technology), work, identity, and nonwork domains, such as race, class, gender, and family. The Appendix summarizes our search criteria. We supplemented the initial list of articles with searches based on references within these articles, arriving at a final pool of 117 articles and books. We coded these materials for factors that seemed to shape people's nonwork identities.

We derived two dimensions that affect how people enact their nonwork identities: (1) workrelated pressures on nonwork identities that emanate principally from organizations and occupations and (2) people's personal preferences regarding the relationship between a particular nonwork identity and their work identity. The dual forces of pressures and preferences each vary along an axis, from inclusion to exclusion. Inclusionary pressures and preferences push people to accept or incorporate a nonwork identity within the work identity; exclusionory pressures and preferences push people to reject or keep nonwork identities separate from the work identity. The labels inclusion and exclusion thus capture concepts related to the integration/ 
segmentation of role boundaries often seen in the work-family literature (Ashforth et al., 2000; Kreiner et al., 2006; Rothbard et al., 2005) and those related to social acceptance/rejection that have been observed with respect to many different social identities in the communication literature, gender literature, and diversity literature (Äbrams, Hogg, \& Marques, 2005; Ashcraft \& Mumby, 2003; Clair et al., 2005; Phillips et al., 2009). The labels also help distinguish the direction of pressures and preferences from frequently noted nonwork identity "states" (e.g., concealed, revealed, integrated, compartmentalized) that we identified from our review and emerge from different configurations of pressures and preferences.

We now define and illustrate pressures, preferences, and commonly occurring nonwork identity states, summarized in Table l. Before proceeding, we offer two caveats: (1) because these studies were originally published for different purposes, our categorizations are necessarily interpretive rather than definitive (Weick \& Quinn, 1999); (2) because people's identity preferences are not always consciously expressed (Banaji, Hardin, \& Rothman, 1993; Costello, 2005), our explanations of these preferences are somewhat speculative.

\section{Work-Related Pressures}

We define work-related pressures on nonwork identities as features of organizations and occupations that influence the meanings people associate with their nonwork identities and how they enact those identities. Meaning and enactment are central and interconnected dimensions of identity construction: interpretation and self-narrative are integral to identity formation (Ashmore, Deaux, \& McLaughlin-Volpe, 2004; Bruner, 1990; Ibarra \& Barbulescu, 2010), and people further establish their selves through behavior and social interaction (Goffman, 1959; Mead, 1934; Swann, 1987).

Work-related pressures may emerge from a variety of organizational and occupational features, including culture (Ely \& Meyerson, 2010; Kunda, 1992), formal structure (Ely, 1995), physical features (Wasserman \& Frenkel, 2011), and policies and practices (Kellogg, 2011). These pressures can be explicit, as when the nonwork identity is overtly targeted (e.g., an organization-sponsored racial affinity group). They may also be implicit, as when the nonwork identity is tacitly affected via pressures exerted on the work identity (e.g., pressures to be an employee who "delivers" may impinge upon one's nonwork identities; Wieland, 2010). The same pressure may be inclusive for some nonwork identities and exclusive for others, as when categories of a nonwork identity are constructed as opposites (e.g., masculine versus feminine gender identities).

Inclusionary pressures. Inclusionary pressures encourage people to incorporate or accept a nonwork identity within their work identity such that its meaning and enactment become a part of the work identity. In occupations, such pressures may emerge through time demands (e.g., apprenticeship periods), space (e.g., where the work is done), and entry restrictions (e.g., professional licensing, kin-based restrictions), as documented in studies of doctors (Becker, Geer, Hughes, \& Strauss, 1961), fishing communities (Davis, 1986), and lacemakers (Sharpe, 2010). Organizations may exert inclusionary pressures through similar conduits, as exemplified by large corporate campuses that colocate office spaces with day care centers, cafeterias, and gymnasiums. Examples include the United States' Googleplex and SAS Institute (Bailyn, Drago, \& Kochan, 2001) and India's Tata Steel campus (Kling, 1998).

Inclusionary pressures may also emerge through workplace practices: network marketing organizations pressure workers to include their family identities within their work identities by encouraging them to view their work as a commitment to their families (Pratt \& Rosa, 2003) and inviting them to transform family and friends into coworkers and clients (Pratt, 2000). Similarly, a law firm explicitly viewed

the insights, skills, and experiences employees have developed as members of various cultural identity groups [as] potentially valuable resources that the work group can use to rethink its primary tasks and redefine its markets, products, strategies, and business practices in ways that will advance its mission (Ely \& Thomas, 2000: 240).

The introduction of new work practices, such as working from home, often facilitated by the spread of communication technology, may also constitute inclusionary pressures on nonwork identities that have typically been excluded from work, such as parent or spouse (Frenkel, 2008). Inclusionary pressures may also be hid- 
TABLE 1

Initial Conditions and Nonwork Identity Management Strategies

\begin{tabular}{|c|c|c|}
\hline Construct & Definition & Example \\
\hline Pressures & \multicolumn{2}{|c|}{$\begin{array}{l}\text { Initial conditions } \\
\text { Organizational and occupational features that influence both the meanings people associate with their } \\
\text { nonwork identities and the enactment of those identities }\end{array}$} \\
\hline $\begin{array}{c}\text { Inclusionary } \\
\text { pressures }\end{array}$ & $\begin{array}{l}\text { Encourage inclusion of a } \\
\text { nonwork identity } \\
\text { within the work } \\
\text { identity }\end{array}$ & $\begin{array}{l}\text { - Corporate campuses with onsite day care centers, cafeterias, gymnasiums, } \\
\text { and concierge services-for example, Tata Steel (Kling, 1998) } \\
\text { - Communication technologies facilitating working from home enable personal } \\
\text { identity to be included in the work identity (Frenkel, 2008) }\end{array}$ \\
\hline $\begin{array}{c}\text { Exclusionary } \\
\text { pressures }\end{array}$ & $\begin{array}{l}\text { Define workers and work } \\
\text { in ways that encourage } \\
\text { exclusion of a nonwork } \\
\text { identity from the work } \\
\text { identity }\end{array}$ & $\begin{array}{l}\text { - Removal of personal claims to the environment, preventing workers from } \\
\text { easily signaling their personal identities (Elsbach, 2003) } \\
\text { - Image of a male engineer excludes women engineers' gender identities from } \\
\text { the definition of a competent engineer (Jorgenson, 2002) }\end{array}$ \\
\hline Preferences & \multicolumn{2}{|c|}{ People's own desires regarding the place of their nonwork identity vis-à-vis the work identity } \\
\hline $\begin{array}{l}\text { Inclusionary } \\
\text { preferences }\end{array}$ & $\begin{array}{l}\text { Desire to include a } \\
\text { particular identity } \\
\text { within a work identity }\end{array}$ & $\begin{array}{l}\text { - A lawyer chose to join a firm where he could do pro bono work based on a } \\
\text { desire to include his volunteer identity into his work identity (Kuhn, 2006) } \\
\text { - A priest wished to reveal a sexual identity in the workplace (Creed, DeJordy, } \\
\text { \& Lok, 2010) }\end{array}$ \\
\hline $\begin{array}{l}\text { Exclusionary } \\
\text { preferences }\end{array}$ & $\begin{array}{l}\text { Desire to separate the } \\
\text { nonwork identity from } \\
\text { the work identity }\end{array}$ & $\begin{array}{l}\text { - One female executive chose to keep her professional side separate from her } \\
\text { family (Bell, 1990). } \\
\text { - One female electrician chose to pass as a man to her coworkers to avoid } \\
\text { harassment based on her sex (Renfrow, 2004) }\end{array}$ \\
\hline
\end{tabular}

Nonwork identity management strategies

Aligned

Assenting

Misaligned

Complying pressure on a nonwork identity, while unobtrusively partially pursuing their own preference
Changing the meaning and enactment of a nonwork identity in a way that conforms to the aligned pressures and preferences

Cases where both pressures and preferences push toward inclusion or exclusion

-To inclusion: A worker reconstructed her social circle within the organization's bounds, encompassing her friend identity solely within her work identity (Hochschild, 1997)

-A software developer described solving a coding problem in his dreams as "sleep-work" (Fleming, 2012: 207)

-To exclusion: A call center worker deleted his national identity (Das, 2007)

-A concert pianist erased this nonwork identity when working as an investment banker (Michel, 2011).

Cases where pressures push toward inclusion and preferences push toward exclusion, or vice versa

-With inclusionary pressures: Attorneys who work for law firms with pro bono requirements may prefer to volunteer for projects unrelated to law but ultimately comply with requirements (Rhode, 2005)

-In an Australian call center where workers were told to "be themselves," one employee noted how she compelled herself "to be the right type of person to work here and make sure you show it" (Fleming \& Sturdy, 2011: 191)

-With exclusionary pressures: Some Indian call center workers who prefer to maintain their national cultural identity may respond to "national identity management" practices that compartmentalize but maintain this identity (Poster, 2007)

Resisting Mounting opposition or limitations to systematic attempts at managerial or organizational control of the nonwork identity (Prasad \& Prasad, 2000)
- Resisting inclusionary pressures: Amway workers may resist pressures to encompass friendships in their work identity (Pratt, 2000)

-Anonymous work bloggers resist promotions despite being good performers so they can continue to blog about their work (Schoneboom, 2007).

- Resisting exclusionary pressures: Israeli Foreign Service workers resisted exclusionary pressures on their Israeli identities by intentionally acting "Israeli" at work (Wasserman \& Frenkel, 2011) 
TABLE 1

(Continued)

\begin{tabular}{|c|c|c|}
\hline Construct & Definition & Example \\
\hline Inverting & $\begin{array}{l}\text { Reorienting the pressure } \\
\text { such that what the } \\
\text { organization or } \\
\text { occupation demands is } \\
\text { ultimately aligned with } \\
\text { their own preferences }\end{array}$ & $\begin{array}{l}\text { - Inverting inclusionary pressures: Lawyers who prosecute rape cases invert } \\
\text { inclusionary pressures on their personal selves by arguing that they must } \\
\text { remain detached to serve the victim (Martin, Schrok, Leaf, \& Von Rohr, 2008) } \\
\text { - Leaders may respond to pressures to bring their personal selves to work by } \\
\text { importing just those personal aspects that match the leader role, excluding } \\
\text { those that do not (Petriglieri \& Stein, 2012) } \\
\text {-Inverting exclusionary pressures: When faced with a work structure change } \\
\text { that threatened airline pilots' masculinity, pilots deepened their claim to } \\
\text { masculinity by constructing themselves as paternalistic figures who embraced } \\
\text { subordinates' empowerment (Ashcraft, 2005) } \\
\text { - An Israeli company that acquired an American firm pressured employees to } \\
\text { separate their national identity from their work identity and see themselves } \\
\text { as global; employees inverted this pressure by using the acquisition to prove } \\
\text { that being Israeli was superior to being American and central to their work } \\
\text { identity (Ailon-Souday \& Kunda, 2003) }\end{array}$ \\
\hline
\end{tabular}

den in the very definition of the "right" worker for a job (Ashcraft, 2012). For example, police officers are taught to exemplify an aggressive form of masculinity, leveraging men's gender identities to bolster their work identities (Prokos \& Padavic, 2002).

Exclusionary pressures. Exclusionary pressures define workers and work in ways that encourage the separation or rejection of the nonwork self from the work identity. An extreme example of such exclusionary pressures involves the attempt to erase a nonwork identity from a worker's self-concept that characterizes many organizational and occupational socialization processes. Socialization often involves the deliberate divestiture of entrants' former allegiances, friendships, and belief systems (Barrett, 1996; Greil \& Rudy, 1984; Van Maonen \& Schein, 1979), as well as disrespecting, invalidating, or creating doubts about the values or meaning of nonwork identities and preventing their enactment (Ashforth, 2001). For instance, surgical residents may be actively discouraged from enacting their family identities. One surgeon, recounting how as a junior resident he had been prohibited from attending his grandmother's funeral, noted, "I'll never forget the reaction from the chief. He was like 'She's not going to know if you're there or not.'" Asked whether the "hospital" needed him, he replied, "Absolutely not. That was about 'You are a surgeon first and your personal life comes second" " (Kellogg, 2011: 59).
Thus, this worker was directly pressured by his superior to subordinate his family identity to his professional identity. Since identities are sustained through situated social interaction (Goffman, 1959; Mead, 1934), preventing nonwork identity enactments may diminish the identity's importance over time. Such pressures are not restricted to professions: Indian call centers pressure workers to slough off their Indian identities through "national identity management practices" (Poster, 2007), such as eating American-style food, neutralizing their accents, and taking American names at work (Mirchandani, 2004; Patel, 2010).

Organizations and occupations may-overtly or covertly-regulate membership according to demographic characteristics, such as race, class, or gender (Chua \& Clegg, 1990; Gorman, 2005; Kirkham \& Loft, 1993), such that those who "slip through the cracks" are pressured to deny or ignore their nonwork identities (e.g., the U.S. military's former "don't ask, don't tell" policy). Just as definitions of work and the "right" workers (Ashcraft, 2012) pressure people to include certain identities, they may exert exclusionary pressures on other identities: the cultural image of the engineer as a man may pressure women engineers to exclude or downplay their gender identities to be competent professionals (Jorgenson, 2002). Sudden changes in the nature of work may also exert implicit pressures to exclude nonwork identities by disrupting cultural proc- 
tices (Kelly, Ammons, Chermack, \& Moen, 2010), spatial configurations (Elsbach, 2003), or power hierarchies (Ashcraft, 2005) previously associated with particular nonwork identities.

\section{Personal Preferences}

People are not always easily molded targets of these pressures: they encounter, interpret, and respond to them based on their personal preferences regarding the relationship of their nonwork identity to their work identity. These preferences may vary across people's nonwork identities: individuals may prefer to include their prosocial identity in their work identity such that they aim to be a social justice lawyer but exclude their racial identity such that they do not identify as a black lawyer.

Many drivers of preferences exist that are independent of organizational/occupational forces. For example, nonwork identity preferences may be grounded in broadly shared cultural ideologies (Lane, 2009; Wieland, 2010), family arrangements (Stone, 2007), and prior experiences (Gerson, 1993). More general drivers of nonwork identity preferences may include the extent to which a nonwork identity offers an aspiration (Higgins, 1987; Markus \& Nurius, 1986), is verified by others (Swann, Bosson, \& Pelham, 2002), or offers a basis for distinctiveness, continuity, self-esteem, belonging, efficacy, and meaning (Cooper \& Thatcher, 2010; Vignoles, Regalia, Manzi, Golledge, \& Scabini, 2006). Based on extraorganizational/occupational factors such as these, people develop preferences about the relationship between their nonwork and work identities, which then inform their interpretation of the pressures they encounter at work.

Inclusionary preferences. Preferences toward including the meaning and enactment of a particular nonwork identity within a work identity can be quite strong. For example, an attorney who chose a firm with a pro bono practice so that he could include his volunteer identity within his paid work identity stated:

I want to embody pro-bono work as part of my career and yeah, I sort of want to embody it totally, and you know, not have this part of you that you don't really care about what you do all day and then you use the non-productive hours to do something you really care about, that just doesn't make sense to me (Kuhn, 2006: 1351).
Preferences for inclusion may also be more moderate, as when people want to engage a nonwork identity in the workplace but not necessarily fully merge it with the work identity. Examples include gay priests navigating the intersection of their personal life with their church life (Creed et al., 2010) and "tempered radicals" who seek to intertwine professional and feminist identities (Meyerson \& Scully, 1995).

Exclusionary preferences. People may also prefer to exclude their nonwork identity from their work identity. For example, in Bell's (1990) study of bicultural black career women, one woman reported that she preferred to "keep my professional side separate from my family. When I leave the job to go home, I become the wife, the mother, the housekeeper. I create it; nobody said I have to do it" (1990: 472). Similar exclusionary preferences have been observed in other studies of female professionals (Jorgenson, 2002; Renfrow, 2004).

\section{Emergent States}

Scholars working in each of the different domains we reviewed have uncovered several nonwork identity states-that is, how the identity actually appears. First, nonwork identities are sometimes reconstructed within the work identity such that they come to be defined wholly in relation to the work identity and are no longer enacted outside of work (Adler \& Adler, 1999; Hochschild, 1997); we label this state encompassed. Nonwork identities are sometimes integrated into the work identity, as when people "blend their individual identities with the occupational and/or organizational identity" but continue to also enact the nonwork identity outside of work (Kreiner et al., 2006: 1046; Roberts, 2005). Sometimes workers actively claim a particular nonwork identity in the work domain but do not merge it with the work identity, as often occurs with stigmatized nonwork identities (Clair et al., 2005; Goffman, 1963). We term this state revealed. Other times nonwork identities are compartmentalized such that they are neither actively claimed nor hidden but are simply kept rigorously separate from the work identity (Bell, 1990). Nonwork identities are also often concealed such that coworkers are unaware that the person holds that identity (Goffman, 1963; Tracy \& Trethewey, 2005). Finally, 
identities are sometimes deleted such that they are removed from the self-concept entirely, a process sometimes called "identicide" (Ashforth, Harrison, \& Corley, 2008).

\section{STRATEGIES FOR THE NEGOTIATION OF NONWORK IDENTITIES}

A schematic of how individuals navigate the dual forces of pressures and preferences to negotiate their nonwork identities at work is presented in Figure 1. In the first column, "Initial conditions," we depict pressures and preferences, arrayed along an axis of inclusion to exclusion. The second column maps how the alignment or misalignment of these initial conditions informs people's experiences of the power relationship between them and the organization/ occupation. The third column describes the strategies individuals adopt to manage their nonwork identities when conditions are aligned/ misaligned. We consider four strategies, one adopted when the dual forces are aligned (assenting) and three adopted when they are misaligned (compliance, resistance, inversion). Under each strategy we label examples of specific nonwork identity states that may emerge.
As depicted in this third column, certain nonwork identity states (e.g., compartmentalized, revealed) are associated with multiple strategies (e.g., compartmentalization of a nonwork identity can be seen as an outcome of either resistance or compliance strategies, depending on the nature of the misalignment). The last column maps the consequences of this nonwork identity negotiation process. We now describe in detail how the experience of alignment and misalignment unfolds, the particular strategies that people adopt, and the states that emerge, beginning with conditions of aligned pressures and preferences and moving to conditions of misalignment (see Figure 2).

\section{Alignment: Assent}

When the dual forces are aligned, people are unlikely to experience the pressures they encounter as an exercise of organizational/ occupational power limiting their ability to achieve their desires. Specifically, people are unlikely to experience "a need to accommodate or resist" organizational or occupational pressures (Ely \& Padavic, 2007: 1131), because pres-

FIGURE 1

A Multilevel and Dynamic Model of the Negotiation of Nonwork Identity States

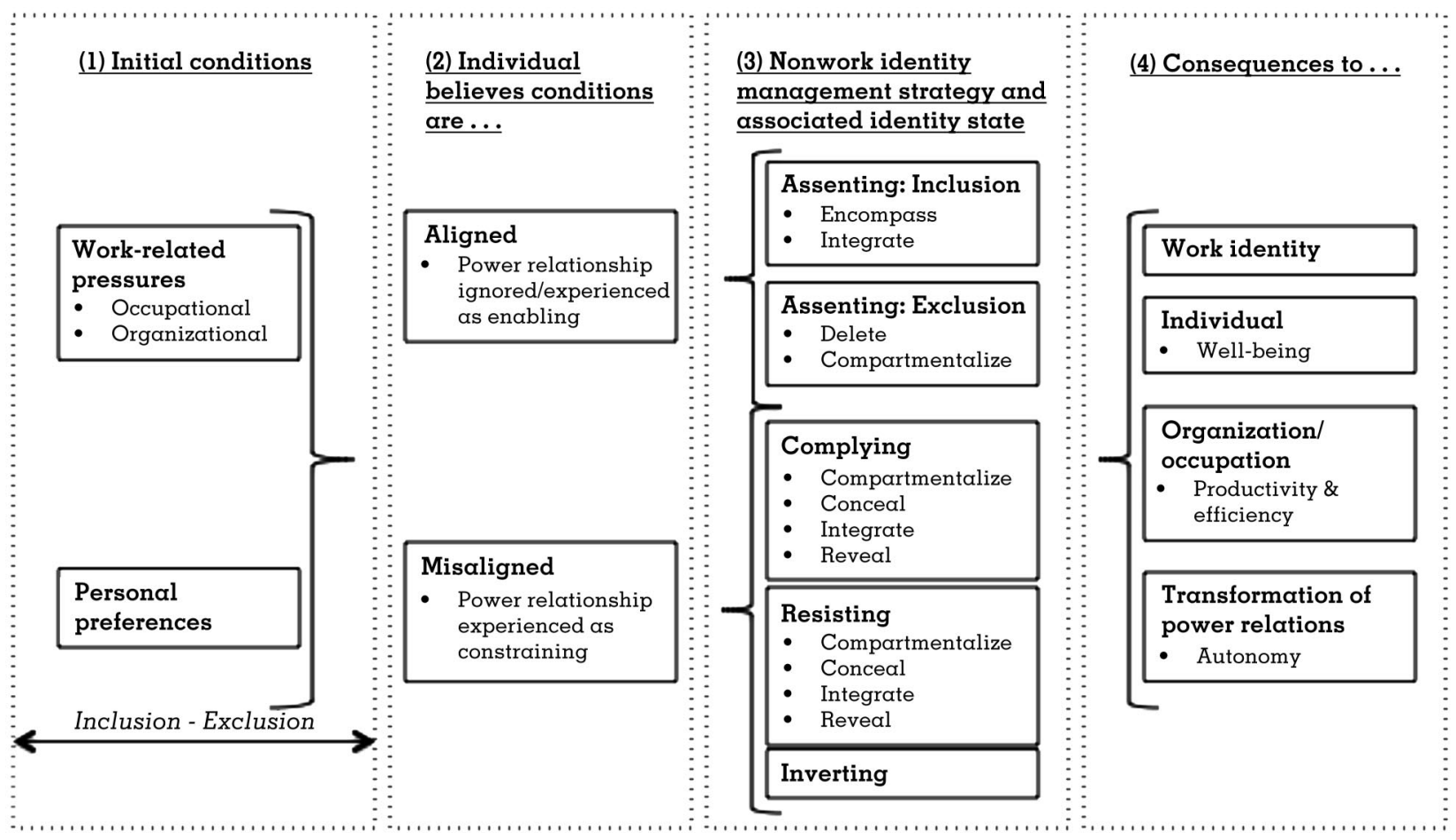


FIGURE 2

Alignment and Misalignment Between Pressures and Preferences

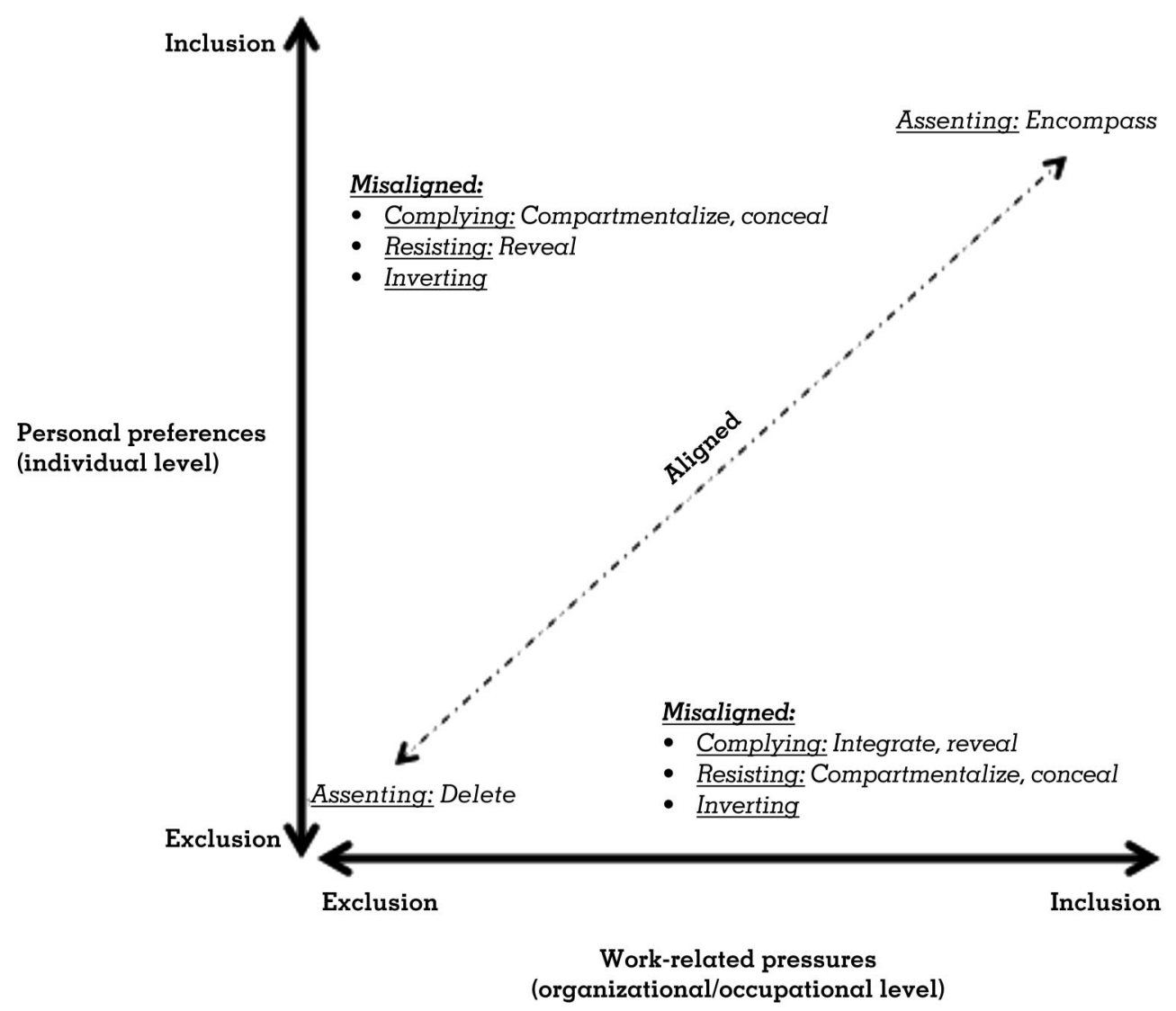

sures do not challenge their preferences for inclusion or exclusion and people's preferences lead them to confirm, validate, and legitimize such pressures (Johnson, Dowd, Ridgeway, Cook, \& Massey, 2006; Nickerson, 1998). Instead, organizational/occupational pressures in this scenario are largely invisible and, thus, go unquestioned, since the imposed relationship between the work and nonwork identity is also desired. Indeed, people in this situation may even experience organizational pressures as enabling. In such situations people are likely to assent to the pressures-that is, to consciously or unconsciously act in accordance with the pressures (e.g., inclusion/exclusion of the nonwork identity).

Assenting to inclusion. When the dual forces are aligned toward inclusion, people are likely to assent to the pressures by encompassing the nonwork identity within the work identity. This occurred in one organization that placed inclusionary pressures on employees' identities as friends: through long hours and a friendly work environment, the organization encouraged employees to reconstruct their social circles within organizational bounds. Those happy to socialize with their work colleagues assented to the pressures and encompassed their identity as a friend in their work identity. One such employee reflected:

I was working sixty to seventy hours a week. I was Little Miss Career. I worked myself into being an expert on my product line and traveled to Germany and Japan.... I'm not a homemaker by temperament, I don't have any friends in the neighborhood. All my friends are worker bees [at my work], and I love my work too (Hochschild, 1997: 88-89).

This woman's identity as a friend was so fully encompassed by her identity as a worker that she could only be a friend to fellow "worker bees." Without further data on her early experiences at the firm, it is difficult to know whether 
she initially preferred such total inclusion; however, her recollection of being fired from her job suggests that she experienced the inclusion as an outcome of her own desires and the pressures as legitimate until she was fired:

I cried and cried for days. My work wasn't just a job to me, it was my life, my blood, my sweat and tears for the past eleven years. And they took that all away with the flick of a pen. It was like going through a divorce!... My friends, the people I care about, were back at the office wondering what the hell was going on (Hochschild, 1997: 93-94).

Employees may also assent to occupational pressures for inclusion. For instance, because luxury resort workers' careers require frequent relocations, they are often "separated from former friends and in the company of new people" (Adler \& Adler, 1999: 47). Many workers in this industry also prefer fluid and noncommittal friendships and romantic relationships. Over time, they respond to the occupational pressures and their own preferences by constructing social circles populated mainly by other transient people, frequently coworkers, who can understand their lifestyles. Thus, like Hochschild's "worker bee," resort workers' friendships, and the way that they construe themselves as friends, ultimately become subsumed within their work identities.

Assenting to exclusion. When the dual forces are aligned toward complete exclusion of a nonwork identity, people may assent by deleting the nonwork identity from their self-concept. Das (2007) documented such a strategy in a study of Indian call centers, where some of the associates, confronted with exclusionary pressures on their national cultural identity, erased this identity from their self-concept, at least partially. One associate, who, following company policy, had adopted an American name in the workplace, later commented:

I chose the name Samuel Andrews because I am a great fan of Harrison Ford. . . . I have seen Blade Runner 36 times. .. . There Harrison Ford had this name Samuel Andrews! . . . I do prefer this name because wherever I went you know like people know me as Samuel. They don't know me as Shubajit. I am popular as Samuel. ... Subhajit doesn't exist anymore! (Das, 2007: 55).

Thus, this worker responded to exclusionary pressures by choosing to exclude his national cultural identity from work and even imported his work persona of Samuel into his nonwork life. Samuel's enthusiastic embrace of his new persona and comment that he is "popular as Samuel" suggest that his preferences may in part have been driven by the lack of attractiveness of his identity as "Shubajit," perhaps because it did not offer sufficient status, selfesteem, or belonging.

While such identicide (Ashforth et al., 2008) can take a great deal of psychological work (Ebaugh, 1988), this phenomenon is less rare than one might think: exclusionary pressures and preferences that jointly lead to deletion have been observed in multiple field studies of organizations (Casey, 1995; Kunda, 1992), including a nine-year ethnography of two investment banks (Michel, 2011).

\section{Misalignment: Complying, Resisting, and Inverting}

Situations of perfect alignment between pressures and preferences are likely to be rare. When people encounter work-related pressures on a nonwork identity that are misaligned with their preferences, they are forced to more substantively confront and engage the organization's or occupation's power to impose a particular relationship between work and nonwork identities. In misaligned situations, pressures challenge people's preferences for inclusion or exclusion, and preferences lead them to consciously or unconsciously call into question the pressures. In coping with the misalignment, they engage one of three possible nonwork identity management strategies: complying with, resisting, or inverting the pressure. Each strategy permits the individual to at least partially follow his or her own preference regarding the nonwork identity.

Complying. Compliance involves outward conformity without internal acceptance (Kelman, 1958). People who comply with pressures partially assent to the organization's pressure to treat a nonwork identity in a particular way while discretely pursuing their personal preferences. Compliance strategies may result in a variety of nonwork identity states: compartmentalizing or concealing in response to exclusionary pressures, or partially integrating or revealing in response to inclusionary pressures.

People with mild exclusionary preferencesthat is, those who prefer to maintain their non- 
work identity as a part of their self-concept but distinct from their work identity-may compartmentalize upon encountering exclusionary pressures on the identity. They thus comply with the pressure to exclude but do not shed the nonwork identity. In contrast to the Indian call center associate Shubajit, who seemed happy to become Samuel, other call center associates preferred to publicly exclude but privately maintain their national cultural identity:

I am two individuals-"Jeff" at work, and "Gaurav" in my social life. Jeff is artificial. It is an artificial soul. It's not me. In this room is Jeff now, but Gaurav is enjoying life outside.... The customers-when they get mad-they are not abusing me, they are only talking to Jeff Miller (Poster, 2007: 295).

Thus, Jeff/Gaurav appeased the organization by excluding his national cultural identity from his work persona but retained the identity as part of his self-concept by compartmentalizing his "ortificial soul" at work away from his "life outside." The quotation suggests that his moderate exclusion preference stemmed from a need to maintain his self-esteem: in keeping Gaurav separate, he kept the customers from directly "abusing" him.

When the nonwork identity is subject to extreme exclusionary pressures, people following a compliance strategy may attempt to conceal the nonwork identity (e.g., Button, 2004; Hewlin, 2009). A lesbian female priest responded to exclusionary pressures on her sexual identity by initially choosing to hide it:

The big question is, parish or wholeness? Or, parish or sexuality. It was this thing that haunted me. But I was in my thirties, and what do we focus on in our thirties? We're supposed to focus on our career. So it was like I had to put that first. They'd never had a woman pastor before. I had to show I was legitimate ... and I was also trying to figure out how to be with this man that I didn't really like all that much, but I was damned determined to make it work, it was going to be OK, that ... [my husband] was going to help make me legitimate (Creed et al., 2010: 1343).

Her struggle in having to choose between "parish and wholeness" suggests that her preference would have been to include her sexual identity in her work identity, rather than keep it separate.

People who encounter the converse situation-inclusionary pressures on a nonwork identity they prefer to exclude-may also com- ply by partially integrating their nonwork identity with their work identity. For example, some attorneys working for law firms with pro bono requirements preferred to invest their volunteer efforts in projects unrelated to law because these projects felt "less like work"; one attorney claimed to "really resent his law firm's requirement of 40 hours of pro-bono legal work per year because he was already very involved in other charitable activities" outside of work (Rhode, 2005: 134). Despite these sentiments, many attorneys do ultimately comply with professional requirements for pro bono work.

Resisting. In situations of misalignment, people may also employ resistance strategies. We define resistance as opposition to systematic attempts at managerial or organizational control (Prasad \& Prasad, 2000: 387). ${ }^{1}$ As with compliance, the particular identity states resulting from resistance may vary depending on the nature of the misalignment. Three states commonly emerge from resistance: revealed identities in response to exclusionary pressures, compartmentalized identities in response to inclusionary pressures, or concealed identities in response to inclusionary pressures.

Resistance to exclusionary pressures typically involves revealing one's nonwork identities in the workplace. A colorful example is the Israeli Foreign Service employees' response to the organization's use of a new office building to discourage "disorderly and boisterous" conduct, seen as an expression of their Israeli identity (Wasserman \& Frenkel, 2011). Employees interpreted the new building's sophisticated design as discouraging "Israeliness" in favor of a Western European diplomat identity. One commented:

When I came here for the first time and I saw all the sophisticated technology, all of a sudden I understood that we're not provincial any more, for better or for worse. For better, because there's no doubt that it's impressive and important that we should show our guests that they're no better than us, that we're not some remote country in the

\footnotetext{
${ }^{1}$ We acknowledge that compliance and resistance are often intertwined. As noted by Prasad and Prasad: "One cannot automatically infer that resistance is taking place on the basis of a specific action ... occurring in the workplace. It is difficult to specify where compliance ends and resistance begins" (2000: 388). We make interpretive distinctions between them here as a heuristic device and raise this issue later in our discussion of limitations and opportunities for future reseorch.
} 
primitive Middle East. For worse, because it's not really Israeli, it's something imported (Wasserman \& Frenkel, 2011: 512).

Some workers resisted the pressure by intentionally acting "Israeli" in the workplaceplaying loud music, speaking loudly-and deliberately showcasing the old building. One explained:

[This] building is not Israeli at all. It's not from here. Israeliness is the togetherness, storytelling, laughter, openness-the building is not like that, but the older compound was. I show this [the old building] to visitors so they can better understand what Israel is, and how it used to be before (Wasserman \& Frenkel, 2011: 517).

This quotation suggests workers' resistance was motivated in part by preferences for the Israeli identity that were undermined by the new "professional" building and associated identity.

People who encounter inclusionary pressures on a nonwork identity they would prefer to exclude may resist the pressure by compartmentalizing or concealing the identity, essentially withholding the nonwork identity. For example, in a study of Amway's direct sales associates, the author notes:

One distributor I interviewed who lost a friend after recruiting him noted, "It seems to bother people ... they like run from it. So I find that I get people [i.e., recruit people] that I don't care too much if they run-you know but people that I like, but I don't know them. They're not part of my daily life (Pratt, 2000: 480).

This sales associate's aversion to losing a friend may have led to a preference to exclude his identity as a friend from his work, leading him to keep his work and nonwork selves separate.

Inversion. In rare cases of misalignment, people neither comply with nor resist pressures but, instead, seek to invert the pressures such that the organization's/occupation's demands are ultimately aligned with their personal preferences. As a result, individuals con act in accordance with both the pressure and their preference. For example, when a work change designed to empower airline crews threatened airline pilots' authority, which was closely intertwined with their masculine identity, pilots deepened their claims to masculinity by constructing themselves as paternalistic figures who benevolently embraced subordinates' empowerment (Ashcraft, 2005). One pilot, describing how he interacted with the now more em- powered junior pilots, played on such fatherly themes:

I don't squelch it too much as long as they're doing something that I want to do. If they were gonna start doing something that I didn't want to do, then I would just say, "Let's not do that," you know. In a way, I kind of like to let them have their leash (Ashcraft, 2005: 82).

In this way the pilots redefined the pressure in a way that allowed them to retain the desired identity (masculinity) while still meeting the work-related goal of enabling crew empowerment. Inclusionary pressures may also be inverted to be exclusionary. Such inversion seems to occur among lawyers prosecuting rape cases, who invert extreme inclusionary pressures on their personal selves by arguing that they must remain detached and objective to best serve the victim (Martin, Schrok, Leaf, \& Von Rohr, 2008).

\section{Consequences of Alignment and Misalignment}

These strategies have implications for work identity and for three important sets of outcomes that arise from existing metatheoretical perspectives on identity: (1) individual well-being and engagement- $a$ human relations perspective; (2) organizational/occupational productivity and efficiency- $a$ functional systems perspective; and (3) individual empowerment and autonomy-a critical/emancipatory perspective (Alvesson et al., 2008; Alvesson \& Willmott, 1992).

Alignment. A key implication of complete alignment for the work identity is that when the nonwork identity is either deleted from or encompassed within the work identity, the work identity becomes more dominant in the selfconcept. For example, our model suggests that, for some people, shedding other time-intensive identities, such as a concert pianist identity, is equivalent to becoming workers whose "hearts, minds and energy" are more completely captured by their work (Michel, 2011).

In the short term, assenting strategies are likely to improve workers' well-being; for instance, fit between workers' preferences for integration or segmentation of work and family roles and their organizations' work-family policies improves satisfaction (Kreiner et al., 2009; Rothbard et al., 2005). Furthermore, because assenting to pressures is likely to render the work identity more central to a person's self-concept, commonly examined outcomes of work identity, 
such as productivity and efficiency, are likely to increase (Cheney \& Tompkins, 1987; Dukerich, Golden, \& Shortell, 2002; Kahn, 1990). Because assenting is seen as a product of one's personal preferences, a sense of autonomy is also likely to be present (Pratt, 2000). In the long term, however, there may be negative consequences for well-being (Michel, 2011), and because organizational/occupational power remains unchallenged in such situations, assenting may limit the possibility of long-term transformation of power relations in the worker's favor (Martorana, Galinsky, \& Rao, 2005).

Misalignment. For the work identity, a key implication of misalignment is that the nonwork identity continues to exist in a state that is somewhat separate from the work identity (e.g., concealed, revealed, integrated, compartmentalized), providing people with alternative meanings and enactments to the work identity. Thus, less central work identities along with more rorely examined work identity formations, such as disidentified or schizo-identified members (Elsbach, 1999; Kreiner \& Ashforth, 2004), may be seen as correlates of misalignment between nonwork identity pressures and preferences.

Complying with pressures is likely to be effortful for the individual and may negatively affect overall short-term well-being (Clair et al., 2005; Goffman, 1963). In the short term, compliance might be interpreted as positive for the organization/occupation, as people attempt at least partially to comply with organizational pressures. However, in the long run, workers' compliance may negatively affect organizational productivity and efficiency through increased turnover (Hewlin, 2009). Compliance may also limit the possibility of longer-term transformation of power relations between the worker and the organization or occupation (Karreman \& Alvesson, 2004).

The consequences of resistance strategies vary according to the nature of the pressures being resisted (i.e., inclusionary versus exclusionary). In the short term, resistance to exclusionary pressures may draw overt attacks on the disfavored nonwork identity, causing psychological suffering (Clair et al., 2005), while resistance to inclusionary pressures may draw relatively fewer attacks, since the organization or occupation may be simply unaware that the nonwork identity exists. However, the act of re- sistance may afford people a sense of personal autonomy and greater well-being (Creed et al., 2010). Resistance strategies are more problematic for organizations and occupations in the short term because the very act of resisting a pressure may reduce a person's commitment to the work (Wasserman \& Frenkel, 2011), hence reducing his or her productivity and efficiency, although it may preserve the potential for longterm transformation and change of power relations (Meyerson \& Scully, 1995).

Inversion strategies offer positive short-term consequences for both people and the organization/occupation. For the individual, inversion promises the best of all worlds in the short term: preserving both the nonwork and the work identity and affording the individual a sense of autonomy (Ashcraft, 2005). For the organization or occupation, the short-term consequences of inversion are more ambiguous, with the individual seemingly conforming to the organization's pressures but, in fact, co-opting those pressures for his or her own ends. Similarly, the long-term consequences may also be ambiguous since inversion does not challenge pressures in a way that might transform power relations within the organization or occupation.

\section{DISCUSSION AND FUTURE RESEARCH}

This article synthesizes empirical research on work and identity to develop new theory about the negotiation of nonwork identities in the context of organizational/occupational pressures and individuals' personal preferences. We suggest that both pressures and preferences are arrayed along an axis of inclusion of the nonwork identity within to exclusion from the work identity and that the alignment/misalignment of these dual forces may affect people's experiences of the power relationship between themselves and the organization and may lead them to craft differing nonwork identity management strategies with distinct consequences. Below we describe some of the theoretical implications of our model for research on work and identity.

\section{Organizational/Occupational Control of Nonwork Identity}

Our multilevel approach contributes to a deeper understanding of how identity control processes rooted in the workplace may pressure 
nonwork identities. Fundamentally, we argue for an extension of the nomological net of scholarship on work and identity to include the study of nonwork identities. Management scholarship on organizational and occupational control of identities has largely focused on the control and "regulation of organization based identities" (Wasserman \& Frenkel, 2011; see also Alvesson \& Willmott, 2002, and Pratt, 2000). Our model suggests that the control of work identities may be understood to proceed alongside the control of nonwork identities.

Furthermore, our theory suggests that these processes are mutually constitutive such that people's construction of a work identity requires managing nonwork identities in a particular way, with critical work-related consequences. For example, in addition to antecedents of work identity, such as organizational/occupational prestige, and the overlap between one's own values and organizational values regarding work (Ashforth \& Mael, 1989; Dutton et al., 1994), we suggest that work identity is also formed by pressures and preferences regarding nonwork identities. Pratt notes that identity management practices shape how members think and feel about themselves in relation to their organization (Pratt, 2000: 456-457). Our model illuminates how the shaping of work identity by organizations/occupations includes influencing how members think and feel about themselves in relation to their nonwork identities. In this way our research also connects research on identity control to research on boundary control (Perlow, 1998). We contend that investigating work identity construction requires understanding the control of both work and nonwork identities.

One way to integrate the study of work identity with the control of nonwork identity would be to identify the organization's or occupation's definition of an ideal worker. As has been discussed, expectations about who ought to conduct particular work (Acker, 1990; Ashcraft, 2012) are constructed in relation to a particular sort of person. Establishing what this person looks like and what he or she does when not at work versus when at work would offer clues to especially salient nonwork identities that are subjected to inclusionary or exclusionary pressures. Scholarship suggests this person is defined through multiple features of the organization or occupation, such as formal and informal hiring criteria (Gorman, 2005), informal cultural practices
(Turco, 2010), and work practices (Ashcraft, 2012). Each of these features offers a useful starting point for future scholarship.

We have focused here on how people negotiate their nonwork identities at work, but the reverse relationship-how nonwork pressures affect people's work identities (e.g., how marital relationships affect the construction of oneself as a worker)-may also be fruitful terrain for future scholarship. Such an approach would also challenge the extent to which work and identity scholarship recreates the "myth of separate worlds" (Kanter, 1977). As with the problems explored in this article, scholars working on topics related to work and family, gender and diversity, communication, and occupational communities likely have much to contribute to a systematic investigation of the relationship between non-work-related pressures and work identities.

\section{Nonwork Identity Management Strategies}

Central to our model is how the alignment or misalignment of pressures and preferences affects people's nonwork identity management strategies. By integrating research on identity across the domains of organizational communication (Barker, 1993; Buzzanell \& Liu, 2005; Jorgenson, 2002), gender and diversity (Blair-Loy, 2003; Ely \& Thomas, 2000), work and family (Ashforth et al., 2000; Kreiner et al., 2009; Pratt \& Rosa, 2003; Rothbard et al., 2005), and occupational community (Adler \& Adler, 1999; Davis, 1986; Kidder, 2006), we were able to examine commonly identified emergent identity states (e.g., concealed, revealed, integrated, etc.). However, our attention to alignment/misalignment of pressures and preferences uncovered how seemingly similar states could arise from vastly different strategies (e.g., compliance versus resistance). For example, Kreiner et al. (2006) found that priests, confronted with extreme inclusionary pressures on their personal identities, use identity work to integrate or differentiate their work and personal identities in pursuit of "optimal balance." In our model their study can be understood as explaining how individuals manage the alignment or misalignment of their preferences with a particular set of inclusionary pressures on a particular nonwork identity. In contrast, Creed and colleagues (2010) examined the same occupation, but, according to 
our model, they examined exclusionary pressures on a different nonwork identity (sexual identity). In both instances similar nonwork identity states emerged (e.g., compartmentalized). "Lumping" these studies together (Gront \& Ashford, 2008) draws attention to the fact that a compartmentalized nonwork identity state may emerge both from resistance to inclusion pressures (Kreiner et al., 2006) and from compliance to exclusion pressures (Creed et al., 2010). The meaning of the identity state, thus, is not fixed and may shift according to the particular configuration of pressures and preferences. Therefore, for the various domains of research we draw upon that have already recognized that people negotiate their nonwork identities at work, such as organizational communication, gender, diversity, or work and family, our model will help deepen our understanding of strategies in addition to states.

We deliberately constructed a simplified model that traces how people negotiate a single nonwork identity; future scholars might complicate our model by considering multiple identities. For instance, to the extent that pressures and preferences are aligned on all of the nonwork identities a person has, the result would be a hegemonic work identity, whereas in other cases a single person may be resisting exclusion pressures on a sexual identity (by revealing) while complying with inclusion pressures on a religious identity (by revealing).

An important question our model generates is how specific strategies may alter or sustain organizational pressures and personal preferences. For example, in the case of alignment, assenting strategies may lead to routinization and reinforcement of initial preferences and pressures because the dual forces are likely to be treated as legitimate and normal. Ultimately, over time and through incremental steps, people's nonwork identities are transferred to the work domain-in the case of alignment toward inclusion-or wither away-in the case of alignment toward exclusion (e.g., the notion of a "perpetually deferred self" is one example of such a self-reinforcing routinized process; Tracy \& Trethewey, 2005).

\section{Problematizing Alignment and Misalignment}

Our model highlights both the positive and the problematic aspects of alignment. Specifi- colly, a key difference between olignment and misalignment is how people experience the power relationship between themselves and their organization or occupation. In the case of alignment, the power relationship may remain unnoticed or be experienced as enabling. However, our analysis of consequences suggests that people acting on their own preferences and in alignment with the organization may still experience long-term decrements in well-being.

We also problematize misalignment. Misalignment involves the experience of being challenged by organizational/occupational pressures, but our analysis of the consequences suggests some productive outcomes of these tensions, such as bounding organizational/ occupational control over aspects of oneself and potentially seeding future change. We thus highlight on intriguing tension between the positive and negative experiences of alignment and misalignment and their consequences.

A fruitful area of future research would be exploring variations in the experience of power in misalignment conditions. We argue that the strategies crafted under misalignment emerge from an experience of oneself in a relationship of power with the organization/occupation; however, in the interests of constructing a simplified model, we do not distinguish further between the three strategies on this dimension. Future research might seek to uncover the moderators that compel people to comply with versus resist versus invert these pressures. Tackling this question may involve a closer examination of the potential overlaps and differences between the identity and power literature from a critical/ emancipatory perspective and from a more positivist perspective. Some ideas raised in our review that may be important to investigate include the degree to which the pressures are invisible and indirect, which may make the extent of power harder to recognize; for example, visible socialization practices may coexist with more invisible control practices that bypass cognition and work through embodied means (Michel, 2011). This theme also arises in recent social psychological explorations of the implicit activation of power (Li, Galinsky, Gruenfeld, \& Guillory, 2011).

This article challenges a "separate worlds" approach to understanding the relationship between work and identity in management scholarship. In making this challenge we join other 
organizational scholars who have recently highlighted the costs of continuing to define "work" as distinct and separable from "nonwork" with respect to understanding a wide range of work and managerial problems (Ashcraft, 2012; Ashforth et al., 2000; Bowles \& McGinn, 2008; Dumas, Phillips, \& Rothbard, in press; Tracy \& Trethewey, 2005; Watson, 2009). We hope our integrated framework generates additional momentum for breaking down the barriers between work and nonwork identities in management scholarship.

\section{APPENDIX: LITERATURE REVIEW SUMMARY}

\section{Years: $1990-2012$}

We used 1990 as a starting point to examine scholarship on these trends because scholarly analyses and major events point to the emergence of these changes in the social organization of work in the late 1980s and early 1990s (Coppelli, 1999; Dobbin, 2009; Gratton, 2011; Smith, 2002; Trefalt, in press). For exomple, the following events correspond to the emergence of the social trends outlined in this article:

- Job insecurity: Contingent employment and job insecurity were discussed in the late 1980s and early 1990s (Newman, 1988), with prominent companies such as IBM moving from a no-layoff policy to involuntary downsizing in the early 1990s (Sennett, 1998).

- Workforce diversity: Diversity management also rose in prominence during the late 1980s and early 1990s (Dobbin, 2009) in the wake of high-profile events, such as Price Waterhouse v. Ann Hopkins (1989) and the testimony of Anita Hill during the nomination of Clarence Thomas in 1991.

- Communication technology: In North American companies the Internet revolution was still in its early stages and mobile phones were not in wide use (Gratton, 2011: 61).

\section{Journals}

To ensure that our review captured the breadth of scholorly interest in work and identity, we chose the following journals: Academy of Monagement Journal, Administrative Science Quarterly, Communication Monographs, Communication Studies, Human Relations, Journal of Organizational Behavior, Management Communication Quarterly, Organization Science, and Organization Studies.

\section{REFERENCES}

Abrams, D., Hogg, M. A., \& Marques, J. M. (Eds.). 2005. The social psychology of inclusion and exclusion. New York: Psychology Press.

Acker, J. 1990. Hierarchies, jobs, bodies: A theory of gendered organizations. Gender \& Society, 7: 139-158.

Adler, P. A., \& Adler, P. 1999. Transience and the postmodern self: The geographic mobility of resort workers. Sociological Quarterly, 40: 31-58.

Ailon-Souday, G., \& Kunda, G. 2003. The local selves of global workers: The social construction of national identity in the face of organizational globalization. Organization Studies, 24: 1073-1096.

Albert, S., Asshforth, B. E., \& Dutton, J. E. 2000. Organizational identity and identification: Charting new waters and building new bridges. Academy of Management Review, 25: 13-17.

Alvesson, M., Ashcraft, K. L., \& Thomas, R. 2008. Identity matters: Reflections on the construction of identity scholarship in organizational studies. Organization, 15: 5-24.

Alvesson, M., \& Billing, Y. D. 1997. Understanding gender and organizations. Thousand Oaks, CA: Sage.

Alvesson, M., \& Willmott, H. 1992. On the idea of emancipation in management and organization studies. Academy of Management Review, 17: 432-464.

Alvesson, M., \& Willmott, H. 2002. Identity regulation as organizational control: Producing the appropriate individual. Journal of Management Studies, 39: 619-644.

Anderson, C., \& Galinsky, A. D. 2006. Power, optimism, and risk-taking. European Journal of Social Psychology, 36: 511-536.

Anteby, M. 2008. Identity incentives as an engaging form of control: Revisiting leniencies in an aeronautic plant. Organization Science, 19: 202-220.

Anteby, M. 2013. Relaxing the taboo on telling our own stories: Upholding professional distance and personal involvement. Organization Science, 24: 1277-1290.

Arthur, M. B., \& Rousseau, D. M. (Eds.). 1996. The boundaryless career: $A$ new employment principle for a new era. New York: Oxford University Press.

Ashcraft, K., \& Mumby, D. K. 2003. Reworking gender: A feminist communicology of organization. Thousand Oaks, CA: Sage.

Ashcraft, K. L. 2005. Resistance through consent? Occupational identity, organizational form, and the maintenance of masculinity among commercial airline pilots. Management Communications Quarterly, 19: 67-90.

Ashcraft, K. L. 2012. The glass slipper: "Incorporating" occupational identity in management studies. Academy of Management Review, 38: 6-31

Ashforth, B. E. 2001. Role transitions in organizational life: An identity-based perspective. Mahwah, NJ: Lawrence Erlbaum Associates. 
Ashforth, B. E., Harrison, S. H., \& Corley, K. G. 2008. Identification in organizations: An examination of four fundamental questions. Journal of Management, 34: 325-374.

Ashforth, B. E., \& Kreiner, G. E. 1999. "How can you do it?" Dirty work and the challenge of constructing a positive identity. Academy of Management Review, 24: 413-434.

Asshforth, B. E., Kreiner, G. E., \& Fugate, M. 2000. All in a day's work: Boundaries and micro role transitions. Academy of Management Review, 25: 472-491.

Ashforth, B. E., \& Mael, F. 1989. Social identity theory and the organization. Academy of Management Review, 14: 2039.

Ashmore, R. D., Deaux, K., \& McLaughlin-Volpe, T. 2004. An organizing framework for collective identity: Articulation and significance of multidimensionality. Psychological Bulletin, 130: 80-114.

Bailey, D. E., \& Kurland, N. B. 2002. A review of telework research: Findings, new directions, and lessons for the study of modern work. Journal of Organizational Behavior, 23: 383-400.

Bailyn, L. 2006. Breaking the mold: Redesigning work for productive and satisfying lives. Ithaca, NY: Cornell University Press.

Bailyn, L., Drago, R., \& Kochan, T. A. 2001. Integrating work and family life: $A$ holistic approach. Report of the Sloan Work-Family Policy Network, MIT, Cambridge, MA.

Banaji, M. R., Hardin, C., \& Rothman, A. J. 1993. Implicit stereotyping in person judgment. Journal of Personality and Social Psychology, 65: 272-281.

Barker, J. R. 1993. Tightening the iron cage: Concertive control in self-managing teams. Administrative Science Quarterly, 38: 408-437.

Barley, S. R., Meyerson, D. E., \& Grodal, S. 2011. E-mail as a source and symbol of stress. Organization Science, 22: 887-906.

Barrett, F. J. 1996. The organizational construction of hegemonic masculinity: The case of the US navy. Gender, Work \& Organization, 3: 129-142.

Bartel, C. 2001. Social comparisons in boundary-spanning work: Effects of community outreach on members' organizational identity and identification. Administrative Science Quarterly, 46(3): 379-313.

Bartel, C., Blader, S. L., \& Wrzesniewski, A. 2007. Identity and the modern organization. Mahwah, NJ: Lawrence Erlbaum Associates.

Becker, H. S. \& Carper, J. W. 1956. The development of identification with an occupation. American Journal of Sociology, 61: 289-298.

Becker, H. S., Geer, B., Hughes, E. C., \& Strauss, A. L. 1961. Boys in white: Student culture in medical school. Chicago: University of Chicago Press.

Bell, E. L. 1990. The bicultural life experience of careeroriented black women. Journal of Organizational Behavior, 11: 459-477.
Bell, E. L. J., \& Nkomo, S. M. 2003. Our separate ways: Black and white women and the struggle for professional identity. Cambridge, MA: Harvard Business School Press.

Blair-Loy, M. 2003. Competing devotions: Career and family among women executives. Cambridge, MA: Harvard University Press.

Bowles, H. R., \& McGinn, K. L. 2008. Untapped potential in the study of negotiation and gender inequality in organizations. Academy of Management Annals, 2: 99-132.

Brickson, S. 2000. The impact of identity orientation on individual and organizational outcomes in demographically diverse settings. Academy of Management Review, 25: 82-101.

Brief, A. P., Umphress, E. E., Dietz, J., Burrows, J. W., Butz, R. M., \& Scholten, L. 2005. Community matters: Realistic group conflict theory and the impact of diversity. Academy of Management Journal, 48: 830-844.

Briscoe, J. P., Hall, D. T., \& Demuth, R. L. F. 2006. Protean and boundaryless careers: An empirical exploration. Journal of Vocational Behavior, 69: 30-47.

Bruner, J. 1990. Acts of meaning. Cambridge, MA: Harvard University Press.

Burke, P. J., \& Stets, J. 2009. Identity theory. New York: Oxford University Press.

Button, S. B. 2004. Identity management strategies utilized by lesbian and gay employees. Group \& Organization Management, 29: 470-494.

Buzzanell, P., \& Liu, M. 2005. Struggling with maternity leave policies and practices: A poststructuralist feminist analysis of gendered organizing. Journal of Applied Communication Research, 33: 1-25.

Buzzanell, P., \& Turner, L. H. 2003. Emotion work revealed by job loss discourse. Journal of Applied Communication Research, 31: 27-57.

Buzzanell, P. M., Meisenbach, R., Remke, R., Liu, M., Bowers, V., \& Conn, C. 2005. The good working mother: Managerial women's sense-making and feelings about workfamily issues. Communication Studies, 56: 261-285.

Calas, M. B., \& Smircich, L. 1996. The "women's" point of view: Feminist approaches to organization studies. London and Thousand Oaks, CA: Sage.

Callanan, G. A., \& Greenhaus, J. H. 2008. The baby boom generation and career management: A call to action. Advances in Developing Human Resources, 10: 70-85.

Cappelli, P. 1999. Career jobs are dead. California Management Review, 42(1): 146-167.

Casey, C. 1995. Work, self and society: After industrialism. London: Sage.

Castells, M. 1998. The power of identity. American Journal of Sociology, 103: 1730-1732.

Castells, M. 1999. The information age: Economy, society and culture. Science, Technology, \& Human Values, 24: 159166.

Chattopadhyay, P. 1999. Beyond direct and symmetrical effects: The influence of demographic dissimilarity on or- 
ganizational citizenship behavior. Academy of Management Journal, 42: 273-287.

Cheney, G., \& Tompkins, P. 1987. Coming to terms with organizational identification and commitment. Central States Speech Journal, 38: 1-15.

Cheryan, S., Plaut, V. C., Davies, P. G., \& Steele, C. M. 2009. Ambient belonging: How stereotypical cues impact gender participation in computer science. Journal of Personality and Social Psychology, 97: 1045-1060.

Chesley, N. 2005. Blurring boundaries? Linking technology use, spillover, individual distress and family satisfaction. Journal of Marriage and the Family, 67: 1237-1248.

Chua, W. F., \& Clegg, S. R. 1990. Professional closure. Theory and Society, 19: 135-172.

Clair, J. A., Beatty, J. E., \& Maclean, T. L. 2005. Out of sight but not out of mind: Managing invisible social identities in the workplace. Academy of Management Review, 30: 78-95.

Cooper, D., \& Thatcher, S. M. B. 2010. Identification in organizations: The role of self-concept orientations and identification motives. Academy of Management Review, 35: 516-538.

Corbett, M. 2004. The outsourcing revolution: Why it makes sense and how to do it right. Chicago: Dearborn Trade.

Costello, C. Y. 2005. Professional identity crisis: Race, class, gender and success at professional schools. Nashville, TN: Vanderbilt University Press.

Covaleski, M. A., Dirsmith, M. W., Heian, J. B., \& Samuel, S. 1998. The calculated and the arowed: Techniques of discipline and struggles over identity in Big Six public accounting firms. Administrative Science Quarterly, 43: 293-327.

Creed, W. E. D., DeJordy, R., \& Lok, J. 2010. Being the change: Resolving institutional contradiction through identity work. Academy of Management Journal, 53: 1336-1364.

Das, D. 2007. Globalization and the theater of work: Exploring identity dynamics in Indian international call centers. Syracuse, NY: Syracuse University.

Davis, D. L. 1986. Occupational community and fishermen's wives in a Newfoundland fishing village. Anthropological Quarterly, 59: 129-142.

Davis-Blake, A., \& Broschak, J. P. 2009. Outsourcing and the changing nature of work. Annual Review of Sociology, 35: 321-340.

Deal, J. J., Altman, D. G., \& Rogelberg, S. G. 2010. Millennials at work: What we know and what we need to do (if anything). Journal of Business and Psychology, 25: 19l199.

DiTomaso, N. 2001. The loose coupling of jobs: The subcontracting of everyone? New York: Plenum Press.

Dobbin, F. 2009. Inventing equal opportunity. Princeton, NJ: Princeton University Press.

Dukerich, J. M., Golden, B. R., \& Shortell, S. M. 2002. Beauty is in the eye of the beholder: The impact of organizational identification, identity, and image on the cooperative behaviors of physicians. Administrative Science Quarterly, 47: 507-533.

Dumas, T. L., Phillips, K. W., \& Rothbard, N. P. In press. Getting closer at the company party: Integration experiences, racial dissimilarity, and workplace relationships. Organization Science.

Dutton, J. E., Dukerich, J. M., \& Harquail, C. V. 1994. Organizational images and member identification. Administrative Science Quarterly, 39: 239-263.

Dutton, J. E., Roberts, L. M., \& Bednar, J. S. 2010. Pathways for positive identity construction at work: Four types of positive identity and the building of social resources. Academy of Management Review, 35: 265-293.

Ebaugh, H. 1988. Becoming an ex: The process of role exit. Chicago: University of Chicago Press.

Elsbach, K. D. 1999. An expanded model of organizational identification. Research in Organizational Behavior, 21: 163-200.

Elsbach, K. D. 2003. Relating physical environment to selfcategorizations: Identity threat and affirmation in a nonterritorial office space. Administrative Science Quarterly, 48: 622-654.

Ely, R., \& Padavic, I. 2007. A feminist analysis of organizational research on sex differences. Academy of Management Review, 32: 1121-1143.

Ely, R. J. 1995. The power of demography: Women's social constructions of gender identity at work. Academy of Management Journal, 38: 589-634.

Ely, R. J., \& Meyerson, D. E. 2010. An organizational approach to undoing gender: The unlikely case of offshore oil platforms. Research in Organizational Behavior, 30: 3-34.

Ely, R. J., \& Thomas, D. A. 2000. Cultural diversity at work: The moderating effects of work group perspectives on diversity. Administrative Science Quarterly, 46: 229-273.

Emerson, R. M. 1962. Power dependence relations. American Sociological Review, 27: 31-41.

Fleming, P. 2012. The birth of biocracy. Research in the Sociology of Organizations, 35: 205-227.

Fleming, P., \& Sturdy, A. 2011. Being yourself in the electronic sweatshop: New forms of normative control. Human Relations, 64: 177-200.

French, J., \& Raven, B. 1959. The bases of social power. In D. Cartwright (Ed.), Studies in social power: 150-165. Ann Arbor, MI: Institute for Social Research.

Frenkel, M. 2008. Reprogramming femininity? The construction of gender identities in the Israeli hi-tech industry between global and local gender orders. Gender, Work \& Organization, 15: 352-374.

Gerson, K. 1993. No man's land: Men's changing commitments to family and work. New York: Basic Books.

Goffman, E. 1959. The presentation of self in everday life. Garden City, NY: Doubleday Anchor Books.

Goffman, E. 1963. Stigma: Notes on the management of spoiled identity. New York: Simon \& Schuster. 
Goldthorpe, J. H., Lockwood, D., Bechhofer, F., \& Platt, J. 1968. The affluent worker: Industrial attitudes and behaviour. London: Cambridge University Press.

Gorman, E. H. 2005. Gender stereotypes, same-gender preferences, and organizational variation in the hiring of women: Evidence from law firms. American Sociological Review, 70: 702-728.

Granovetter, M. S. 1973. The strength of weak ties. American Journal of Sociology, 78: 1360-1380.

Grant, A., \& Ashford, S. 2008. The dynamics of proactivity at work. Research in Organizational Behavior, 28: 3-34.

Gratton, L. 2011. The future of work is already here. London: HarperCollins.

Greenhaus, J. H., \& Beutell, N. J. 1985. Sources of conflict between work and family roles. Academy of Management Review, 10: 76-88.

Greenhaus, J. H., \& Powell, G. 2006. When work and family are allies: A theory of work-family enrichment. Academy of Management Review, 31: 72-92.

Greil, A. L., \& Rudy, D. R. 1984. Social cocoons: Encapsulation and identity transformation organizations. Sociological Inquiry, 54: 260-278.

Hewlin, P. F. 2009. Wearing the cloak: Antecedents and consequences of creating facades of conformity. Journal of Applied Psychology, 94: 727-741.

Higgins, E. T. 1987. Self-discrepancy: A theory relating self and affect. Psychological Review, 94: 319-340.

Higgins, M. C. 2001. Changing careers: The effects of social context. Journal of Organizational Behavior, 22: 595-618.

Higgins, M. C., \& Thomas, D. A. 2001. Constellations and careers: Toward understanding the effects of multiple developmental relationships. Journal of Organizational Behavior, 22: 223-247.

Ho, K. 2009. Liquidated: An ethnography of Wall Street. Durham, NC: Duke University Press.

Hochschild, A. R. 1997. The time bind: When work becomes home and home becomes work. New York: Henry Holt.

Ibarra, H. 1999. Provisional selves: Experimenting with image and identity in professional adaptation. Administrative Science Quarterly, 44: 764-79l.

Ibarra, H. 2003. Working identity: Unconventional strategies for reinventing your career. Cambridge, MA: Harvard Business School Press.

Ibarra, H., \& Barbulescu, R. 2010. Identity as narrative: Prevalence, effectiveness, and consequences of narrative identity work in macro work role transitions. Academy of Management Review, 35: 135-154.

James, W. 1890. The consciousness of self. Principles of Psychology, 1: 291-401. New York: Henry Holt.

Johnson, C., Dowd, T. J., Ridgeway, C. L., Cook, K. S., \& Massey, D. S. 2006. Legitimacy as a social process. Annual Review of Sociology, 32: 53-78.

Jorgenson, J. 2002. Engineering selves: Negotiating gender and identity in technical work. Management Communications Quarterly, 15: 350-380.
Kahn, W. A. 1990. Psychological conditions of personal engagement and disengagement at work. Academy of Management Journal, 33: 692-724.

Kalleberg, A. L. 2009. Precarious work, insecure workers: Employment relations in transition. American Sociological Review, 74: 1-22.

Kanter, R. M. 1977. Work and family in the United States: $A$ critical review and agenda for research and policy. New York: Russell Sage Foundation.

Karreman, D., \& Alvesson, M. 2004. Cages in tandem: Management control, social identity and identification in a knowledge-intensive firm. Organization, 11: 149-175.

Kellogg, K. C. 2011. Challenging operations: Medical reform and resistance in surgery. Chicago: University of Chicago Press.

Kelly, E. L., Ammons, S. K., Chermack, K., \& Moen, P. 2010. Gendered challenge, gendered response: Confronting the ideal worker norm in a white collar organization. Gender \& Society, 24: 281-303.

Kelman, H. 1958. Compliance, identification and internalization: Three processes of attitude change. Journal of Conflict Resolution, 2: 51-60.

Kidder, J. L. 2006. "It's the job that I love": Bike messengers and edgework. Sociological Forum, 21: 31-54.

Kirkham, L. M., \& Loft, A. 1993. Gender and the construction of the professional accountant. Accounting, Organizations and Society, 18: 507-558.

Kling, B. B. 1998. Paternalism in Indian labor: The Tata Iron and Steel Company of Jamshedpur. International Labor and Working-Class History, 53: 69-87.

Knights, D., \& Vurdubakis, T. 1994. Foucault, power, resistance and all that. In D. K. J. Jermier \& W. R. Nord (Eds.), Resistance and power in organizations: 167-198. London: Routledge.

Konrad, A. M. 2003. Special issue introduction: Defining the domain of workplace diversity scholarship. Group \& Organization Management, 28: 4-17.

Kreiner, G. E., \& Ashforth, B. E. 2004. Evidence toward an expanded model of organizational identification. Journal of Organizational Behavior, 25: 1-27.

Kreiner, G. E., Hollensbe, E. C., \& Sheep, M. L. 2006. Where is the "me" among "we"? Identity work and the search for optimal balance. Academy of Management Journal, 49: 1031-1057.

Kreiner, G. E., Hollensbe, E. C., \& Sheep, M. L. 2009. Balancing borders and bridges: Negotiating the work-home interface via boundary work tactics. Academy of Management Journal, 52: 704-730.

Kuhn, T. 2006. A "demented work ethic" and a "lifestyle firm": Discourse, identity, and workplace time commitments. Organization Studies, 27: 1339-1358.

Kunda, G. 1992. Engineering culture: Control and commitment in a high-tech corporation. Philadelphia: Temple University Press. 
Ladge, J., Clair, J., \& Greenberg, D. 2012. Cross-domain identity transition during liminal periods: Constructing multiple selves as professional and mother during pregnancy. Academy of Management Journal, 55: 1449-1471.

Lamont, M., \& Molnór, V. 2002. The study of boundaries in the social sciences. Annual Review of Sociology, 28: 167-195.

Lane, C. 2009. A company of one: Insecurity, independence, and the new world of white-collar unemployment. Ithaca, NY: Cornell University Press.

Leonardi, P., \& Bailey, D. E. 2008. Transformational technologies and the creation of new work practices: Making implicit knowledge explicit in task-based offshoring. MIS Quarterly, 32: 411-436.

Li, H., Galinsky, A. D., Gruenfeld, D. H., \& Guillory, L. E. 2011. Powerful postures versus powerful roles: Which is the proximate correlate of thought and behavior? Psychological Science, 6: 95-102.

Lucas, K. 2009. Creating and responding to the gen(d)eralized other: Women ministers' community-constructed identities. Women's Studies in Communication, 32: 320347.

MacKenzie, R., Stuart, M., Forde, C., Greenwood, I., Gardiner, J., \& Perrett, R. 2006. "All that is solid?" Class, identity and the maintenance of a collective orientation among redundant steelworkers. Sociology, 40: 833-885.

Markus, H., \& Nurius, P. 1986. Possible selves. American Psychologist, 41: 954-969.

Martin, P. Y., Schrok, D., Leaf, M., \& Von Rohr, C. 2008. Rape work: Emotional dilemmas in work with victims. In S. Fineman (Ed.), The emotional organization: Passions and power: 44-60. Malden, MA: Blackwell.

Martorana, P., Galinsky, A., \& Rao, H. 2005. From system justification to system condemnation: Antecedents of attempts to change power hierarchies. Research on Managing Groups and Teams, 7: 285-315.

Mead, G. H. 1934. Mind, self and society. Chicago: University of Chicago Press.

Meyerson, D. E., \& Scully, M. A. 1995. Tempered radicalism and the politics of ambivalence and change. Organization Science, 6: 585-600.

Michel, A. 2011. Transcending socialization: A nine-year ethnography of the body's role in organizational control and knowledge workers' transformation. Administrative Science Quarterly, 56: 325-368.

Mirchandani, K. 2004. Webs of resistance in transnational call centers: Strategic agents, service providers and customers. In R. Thomas, A. Mills, \& J. H. Mills (Eds.), Identity politics at work: Resisting gender, gendering resistance: 179-195. London: Routledge.

Newman, K. S. 1988. Falling from grace: Downward mobility in the age of affluence. Berkeley: University of California Press.

Nickerson, R. S. 1998. Confirmation bias: A ubiquitous phenomenon in many guises. Review of General Psychology, 2: 175-220.
Nippert-Eng, C. 1996. Home and work: Negotiating boundaries through everyday life. Chicago: University of Chicago Press.

Patel, R. 2010. Working the night shift: Women in India's call center industry. Palo Alto, CA: Stanford University Press.

Perlow, L. 1998. Boundary control: The social ordering of work and family time in a high-tech corporation. Administrative Science Quarterly, 43: 328-357.

Perlow, L. 2012. Sleeping with your smartphone: How to break the 24/7 habit and change the way you work. Boston: Harvard Business Review Press.

Petriglieri, G., \& Stein, M. 2012. The unwanted self: Projective identification in leaders' identity work. Organization Studies, 33: 1217-1235.

Phillips, K. W., Rothbard, N. P., \& Dumas, T. L. 2009. To disclose or not to disclose? Status distance and selfdisclosure in diverse environments. Academy of Management Review, 34: 710-732.

Poster, W. 2007. Who's on the line? Indian call center agents pose as Americans for US-outsourced firms. Industrial Relations Journal, 46: 271-304.

Prasad, P., \& Prasad, A. 2000. Stretching the iron cage: The constitution and implications of routine workplace resistance. Organization Science, 11: 387-403.

Pratt, M. G. 2000. The good, the bad, and the ambivalent: Managing identification among Amway distributors. Administrative Science Quarterly, 45: 456-493.

Pratt, M. G., Rockmann, K. W., \& Kaufmann, J. B. 2006. Constructing professional identity: The role of work and identity learning cycles in the customization of identity among medical residents. Academy of Management Journal, 49: 235-262.

Pratt, M. G., \& Rosa, J. A. 2003. Transforming work-family conflict into commitment in network marketing organizations. Academy of Management Journal, 46: 395-418.

Presser, H. B. (Ed.). 1998. Toward a 24 hour economy: The US experience and implications for the family. New York: Walter de Gruyter.

Price Waterhouse v. Hopkins, 490 U.S. 228 (1989).

Prokos, A., \& Padavic, I. 2002. "There oughtta be a law against bitches": Masculinity lessons in police academy training. Gender, Work \& Organization, 9: 439-459.

Randel, A. E. 2002. Identity salience: A moderator of the relationship between group gender composition and work group conflict. Journal of Organizational Behavior, 23: 749-766.

Renfrow, D. G. 2004. A cartography of passing in everyday life. Symbolic Interaction, 27: 485-506.

Rhode, D. L. 2005. Pro bono in principle and in practice: Public service and the professions. Stanford, CA: Stanford University Press.

Ridgeway, C. L. 2011. Framed by gender: How gender inequality persists in the modern world. New York: Oxford University Press. 
Roberts, L. M. 2005. Changing faces: Professional image construction in diverse organizational settings. Academy of Management Review, 30: 685-711.

Rothbard, N. P. 2001. Enriching or depleting? The dynamics of engagement in work and family roles. Administrative Science Quarterly, 46: 655-684.

Rothbard, N. P., Phillips, K. W., \& Dumas, T. L. 2005. Managing multiple roles: Work-family policies and individuals' desires for segmentation. Organization Science, 16: 243-258.

Schoneboom, A. 2007. Diary of a working boy. Ethnography, 8: $403-423$.

Scott, C. R. 1997. Identification with multiple targets in a geographically dispersed organization. Management Communications Quarterly, 10: 491-522.

Scott, C. R. 1999. The impact of physical and discursive anonymity on group members' multiple identifications during computer-supported decision making. Western Journal of Communications, 63: 456-487.

Scott, C. R., \& Timmerman, C. E. 1999. Communication technology use and multiple workplace identifications among organizational teleworkers with varied degrees of virtuality. IEEE Transactions on Professional Communication, 42: 240-260.

Sennett, R. 1998. The corrosion of character: The personal consequences of work in the new capitalism. New York: Norton.

Sharpe, P. 2010. Lace and place: Women's business in occupational communities in England 1550-1950. Women's History Review, 19: 283-306.

Smith, V. 2002. Crossing the great divide: Worker risk and opportunity in the new economy. Ithaca, NY: ILR Press.

Stickney, L. T., \& Konrad, A. M. 2007. Gender-role attitudes and earnings: A multinational study of married women and men. Sex Roles, 57: 801-811.

Stone, P. 2007. Opting out? Why women really quit careers and head home. Berkeley and Los Angeles: University of Colifornia Press.

Strangleman, T. 2001. Networks, place and identities in postindustrial mining communities. International Journal of Urban and Regional Research, 25: 253-267.

Strangleman, T. 2007. The nostalgia for permanence at work? The end of work and its commentators. Sociological Review, 55: 81-103.

Svenningson, S., \& Alvesson, M. 2003. Managing managerial identities: Organizational fragmentation, discourse and identity struggle. Human Relations, 64: 85-107.

Swann, W. B. 1987. Identity negotiation: Where two roads meet. Journal of Personality and Social Psychology, 53: 1038-1051.

Swann, W. B., Bosson, J. K., \& Pelham, B. W. 2002. Different partners, different selves: Strategic verification of circumscribed identities. Personality and Social Psychology Bulletin, 28: 1215-1228.
Swann, W. B., Polzer, J., Seyle, D., \& Ko, S. 2004. Finding value in diversity: Verification of personal and social selfviews in diverse groups. Academy of Management Review, 29: 9-27.

Taylor, M. C. 1998. How white attitudes vary with the racial composition of local populations: Numbers count. American Sociological Review, 63: 512-535.

Thatcher, S. M. B., \& Greer, L. L. 2008. Does it really matter if you recognize who I am? The implications of identity comprehension for individuals in work teams. Journal of Management, 34: 5-24.

Thatcher, S. M. B., \& Zhu, X. 2006. Changing identities in a changing workplace: Identification, identity enactment, self-verification, and telecommuting. Academy of Management Review, 31: 1076-1088.

Tracy, S. J., \& Trethewey, A. 2005. Fracturing the real-self $\leftrightarrow$ fake-self dichotomy: Moving toward "crystallized" organizational discourses and identities. Communication Theory, 15: 168-195.

Trefalt, S. In press. Between you and me: Setting worknonwork boundaries in the context of workplace relationships. Academy of Management Journal.

Tsui, A. S., Egan, T. D., \& O’Reilly, C. A. 1992. Being different: Relational demography and organizational attachment. Administrative Science Quarterly, 37: 549-579.

Turco, C. J. 2010. Cultural foundations of tokenism: Evidence from the leveraged buyout industry. American Sociological Review, 76: 894-913.

Van Maanen, J., \& Barley, S. R. 1984. Occupational communities: Culture and control in organizations. Research in Organizational Behavior, 6: 287-365.

Van Maanen, J., \& Schein, E. H. 1979. Toward a theory of organizational socialization. Research in Organizational Behavior, 1: 209-264.

Vignoles, V. L., Regalia, C., Manzi, C., Golledge, J., \& Scabini, E. 2006. Beyond self-esteem: Influence of multiple motives on identity construction. Journal of Personality and Social Psychology, 90: 308-333.

Wasserman, V., \& Frenkel, M. 2011. Organizational aesthetics: Caught between identity regulation and culture jamming. Organization Science, 22: 503-521.

Watson, T. J. 2009. Narrative, life story and manager identity: A case study in autobiographical identity work. Human Relations, 62: 425-452.

Weick, K. E., \& Quinn, R. E. 1999. Organizational change and development. Annual Review of Psychology, 50: 361-386.

Whyte, W. H. 1957. The organization man. Garden City, NY: Doubleday Anchor Books.

Wieland, S. M. B. 2010. Ideal selves as resources for the situated practice of identity. Management Communications Quarterly, 24: 503-528.

Wiesenfeld, B. M., Raghuram, S., \& Garud, R. 1999. Communication patterns as determinants of organizational identification in a virtual organization. Organization Science, 10: 777-790.

Williams, J. C. 2000. Unbending gender: Why family and 
work conflict and what to do about it. New York: Oxford University Press.
Zelizer, V. 2005. The purchase of intimacy. Princeton, NJ: Princeton University Press.

Lakshmi Ramarajan (lramarajan@hbs.edu) is an assistant professor in the Organizational Behavior Unit at Harvard Business School. She received her Ph.D. from the Wharton School of Business, University of Pennsylvania. Her research examines how people manage their multiple identities in organizations.

Erin Reid (erinreid@bu.edu) is an assistant professor of organizational behavior at Boston University School of Management. She received her Ph.D. from Harvard University. She studies how men and women cope with time-greedy work, the consequences for their own lives, and the consequences for their organizations. 